\title{
Rancang Bangun Lengan Robot Otomatis Pengawas Konveyor Pada Pabrik Teh Berbasis Arduino Uno
}

\author{
Widyo Ari Utomo*1, Anton Respati Pamungkas ${ }^{2}$, Abraham Patria Yudha Krisnanda ${ }^{3}$ \\ ${ }^{13}$ Program Studi Sistem Komputer ${ }^{2}$ Program Studi Sistem Informasi; \\ ${ }^{123}$ STMIK AUB Surakarta, Indonesia \\ e-mail: *1widyoari@stmik-aub.ac.id, ${ }^{2}$ anton18@stmik-aub.ac.id, ${ }^{3}$ abraham.pyk@gmail.com
}

\begin{abstract}
Abstrak
Penggunaan lengan robot pada dunia industri salah satunya dapat diaplikasikan sebagai alat pemindah benda. Lengan robot pemindah benda berdasarkan halangan berupa teh yang jatuh adalah lengan robot yang digunakan untuk melakukan pekerjaan secara otomatis memindah benda berdasarkan jarak yang telah ditentukan sebelumnya dan menempatkannya sesuai tempat yang telah disesuaikan. Terdapat cara pengoperasian, yaitu dengan cara otomatis. Dengan sistem otomatis lengan robot akan bekerja sesuai dengan pembacaan dari sensor. Digunakan sensor garis yaitu infrared dan photodioda dan sensor ultrasonik untuk pembacaan jarak apabila terdapat halangan berupa teh yang jatuh yang selanjutnya diproses oleh arduino. Lalu lengan robot dan penjepit sebagai aktuator melaksakan tugasnya sesuai dari pembacaan sensor.
\end{abstract}

Kata kunci: sensor infrared dan photodioda, sensor ultrasonik, arduino

\section{PENDAHULUAN}

Perkembangan teknologi saat ini begitu pesat, demikian pula dengan perkembangan teknologi elektronika. Robotika merupakan bukti peradaban manusia yang semakin maju dari waktu ke waktu. Wujud robot bukan hanya sebuah bentuk yang menyerupai manusia atau binatang tertentu, melainkan bergerak menyerupai bentuk yang ditirunya.

Robot manipulator adalah konstruksi robot yang memiliki bentuk hanya sebuah lengan saja. Robot ini memiliki actuator berupa motor untuk menggerakkan seluruh bagian robot tersebut. Robot manipulator atau lengan robot ini sangat bermanfaat dan cukup banyak dipakai dalam bidang industri. Terutama dalam bagian packing dalam suatu pabrik. Selain untuk menghemat waktu, robot ini digunakan karena hasil yang diperoleh juga lebih baik daripada hasil yang dikerjakan oleh manusia.

Dalam hal ini lengan robot pada system ini digunakan untuk mengambil dan memindahkan benda. Berat benda yang diangkat diharuskan mempunyai dua sisi yang rata sehingga dapat dijepit oleh grip pada lengan robot.

Salah satu pabrik yang membutuhkan robot manipulator atau lengan robot adalah pabrik teh gunung subur Tujuan penelitian ini adalah membuat Lengan Robot Otomatis Pengawas Konveyor pada Pabrik Teh dengan menggunakan teknologi line follower yang mencakup panjang konveyor. Lengan robot ini dibuat otomatis untuk mengambil kemasan teh pack yang terjatuh dengan sistem berjalan maju mengikuti jalur lalu pada saat sensor jarak mendeteksi benda yang menghalang maka itu dianggap kemasan teh pack yang terjatuh dan lengan robot akan mengambil penghalang tersebut lalu mengarahkannya ke permukaan konveyor.

\section{METODE PENELITIAN}

Received May 3, 2018; Revised May 25, 2018; Accepted June 10, 2018 


\subsection{Prosedur penelitian}

Langkah-langkah penelitian dan pengembangan dapat digambarkan seperti gambar blok diagram dibawah

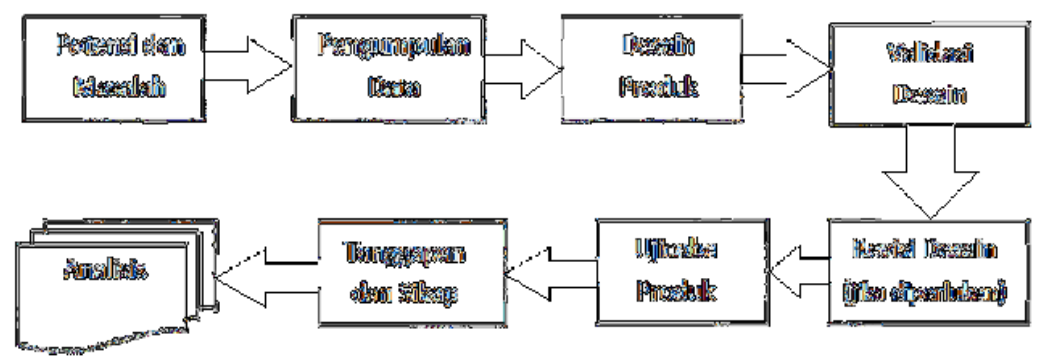

Gambar 1 Prosedur penelitian pendekatan praktik

a. Potensi dan masalah

Persiapan awal dalam penelitian ini, peneliti melakukan melakukan observasi awal untuk identifikasi masalah, kemudian dilanjutkan melalui wawancara tentang media yang digunakan selama ini.

b. Pengumpulan data

Sumber data dalam penelitian ini berasal dari observasi, wawancara dan studi pustaka.

c. Desain Produk

Tahap perancangan (design) dalam penelitian ini adalah membuat secara rinci diagram blok, rangkaian sensor garis modular, rangkaian sensor infrared dan photodiode modular, rangkaian driver motor dan flowchart program.

d. Validasi Desain

Tahap validasi desain, menilai apakah rancangan produk telah sesuai dengan rancangan sebelumnya.

e. Revisi Desain

Tahap revisi desain dilakukan jika diperlukan, karena ada kekurangan dalam desain.

f. Ujicoba Produk

Produk yang telah selesai diuji cobakan sesuai skenario pengujian.

g. Tanggapan dan Sikap

Setelah diujicobakan akan ditentukan tanggapan respon dari produk situasi scenario.

h. Analisis

Tahap ini merupakan penyimpulan hasil dari penelitian.

\subsection{Kebutuhan Perangkat Keras (Hardware)}

Spesifikasi minimum perangkat keras (hardware) yang dibutuhkan untuk membangun dengan spesifikasi sebagai berikut:

Tabel 1 Spesifikasi minimum perangkat keras (hardware)

\begin{tabular}{|c|l|l|}
\hline No & \multicolumn{1}{|c|}{ Jenis } & \multicolumn{1}{c|}{ Kebutuhan } \\
\hline 1 & Komputer Laptop & RAM 2 GB, Harddisk 120GB \\
\hline 2 & Arduino Uno R3 & Papan induk pengembangan \\
\hline 3 & Sensor Ultrasonik & $\begin{array}{l}\text { Pendeteksi jarak lengan robot dengan } \\
\text { produk teh pack yang terjatuh dan } \\
\text { konveyor }\end{array}$ \\
\hline 4 & Sensor Infrared & $\begin{array}{l}\text { Digunakan untuk memilih jalur yang } \\
\text { dilewati lengan robot }\end{array}$ \\
\hline 5 & Sensor Photodioda & $\begin{array}{l}\text { Bekerja bersama sensor infrared untuk } \\
\text { memilih jalur yang dilewati lengan } \\
\text { robot }\end{array}$ \\
\hline 6 & Motor Servo SG90 & $\begin{array}{l}\text { Menggerakan lengan robot dengan } \\
\text { putaran 180 derajat }\end{array}$ \\
\hline
\end{tabular}

Rancang Bangun Lengan Robot Otomatis Pengawas Konveyor Pada Pabrik Teh Berbasis 


\begin{tabular}{|c|l|l|}
\hline 7 & $\begin{array}{l}\text { Trafo 9 volt 2 amphere non CT } \\
\text { (Center Tap) }\end{array}$ & $\begin{array}{l}\text { Kebutuhan daya output komponen 9V } \\
\text { dan 2A }\end{array}$ \\
\hline 8 & Motor DC 5V & Sebagai output pada alat \\
\hline
\end{tabular}

\section{HASIL DAN PEMBAHASAN}

Pada bagian ini akan dijelaskan penggunaan lengan robot, diantara lain :

a. Pengujian Penjapit Lengan Robot

Pengujian dilakukan untuk mengetahui seberapa kekuatan penjapit mampu mengangkat beban yang akan diangkat dan dipindahkan oleh penjapit.

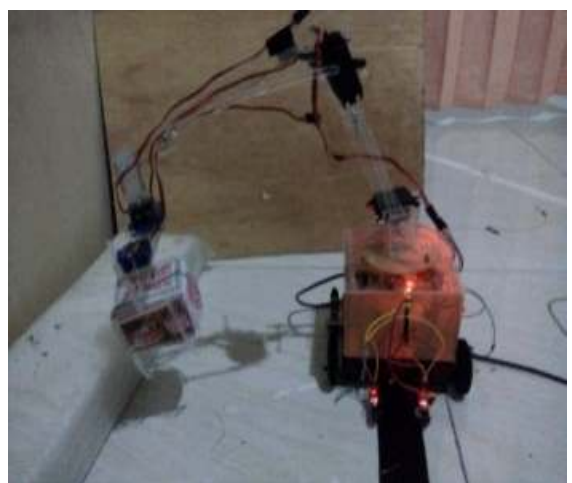

b. Pengujian Servo

Gambar 2 Lengan Robot mengngkat Teh yang jatuh.

Pengujian lengan robot dilakukan dengan tujuan mengetahui berapa derajat kemampuan motor servo yang digunakan agar lengan robot mampu mengambil, memindahkan dan meletakkan teh yang terjatuh pada konveyor.

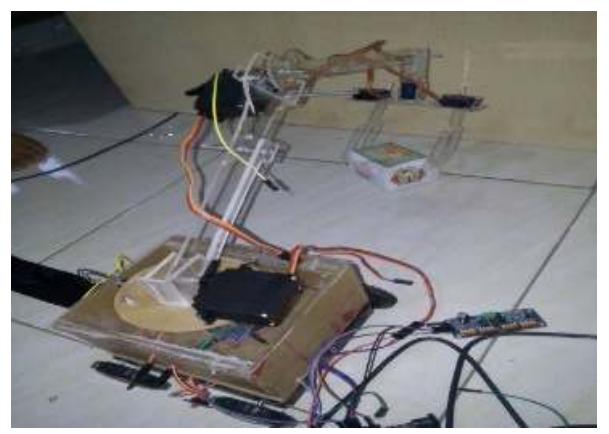

Gambar 3 Sudut Kemirigan Lengan Robot.

c. Pengujian Roda dan Sensor Garis (Infrared dan Photodioda) Pada Robot

Pengujian roda penggerak robot memiliki tujuan untuk apakah sensor garis (infrared danphotodioda) dapat berfungsi dengan baik atau tidak dalam pembacaan antara gelap dan terang. Jika sensor garis (infrared dan photodioda) membaca warna putih roda akan bergerak maju, jika sensor membaca warna hitam maka roda akan berhenti dan robot akan bergerak sesuai dengan warna hitam yang telah ditentukan terlebih dahulu. 


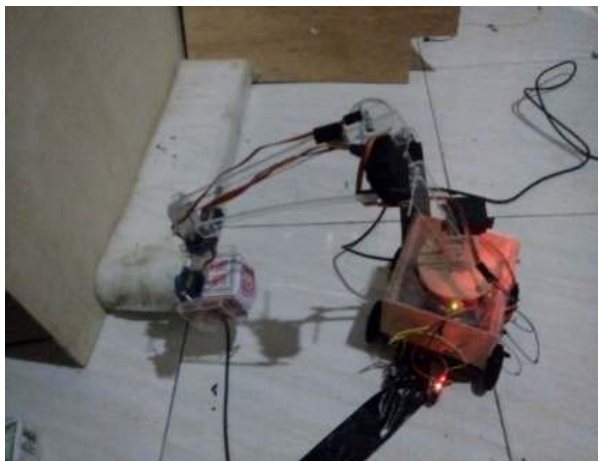

Gambar 4 Robot Akan Berbelok Kekanan Jika Sensor Garis Tidak Membaca cahaya

d. Pengujian Sensor Ultrasonik

Sensor penghalang berfungsi untuk mendeteksi penghalang yaitu berupa teh yang terjatuh di tanah sehingga arduino dapat memerintahkan servo nomor 2 untuk bergerak ke arah teh, servo nomor 3 untuk menurunkan lengan atas, serta memerintah servo nomor 4, 5 dan 6 untuk mengambil teh dengan penjapit.

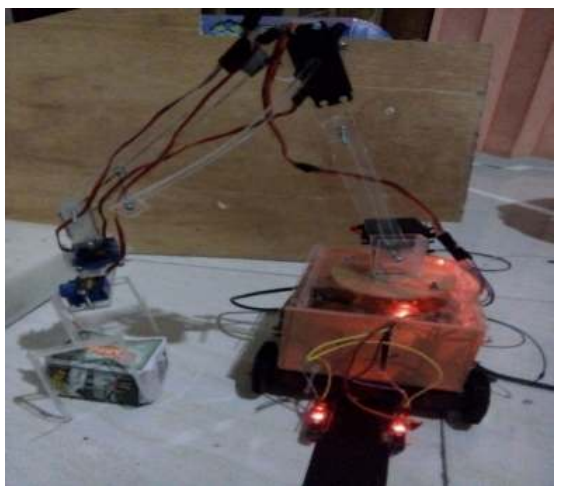

Gambar 5 Penjapit Mengambil Teh Yang Terjatuh Dengan Bantuan Sensor Ultrasonik.

e. Prinsip Kerja Alat

Dalam proses penggunaan alat ini memiliki prinsip kerja yaitu:

1) Saat robot dalam kondisi menyala makan roda penggerak robot sesuai dengan sensor garis (infrared dan photodioda) yang membaca warna gelap dan warna terang pada jalur yang telah disediakan.

2) Setelah berjalan dan sensor penghalang membaca dan menemukan penghalang berupa bungkus teh yang terjatuh ditanah maka roda akan berhenti dan motor servo akan bergerak untuk mengambil bungkus teh yang terjatuh tersebut untuk diletakkan di atas konveyor yang telah tersedia.

\section{KESIMPULAN}

Berdasarkan dari hasil perancangan dan pengujian lengan robot dengan mikrokontroler Arduino Uno R3 menggunakan sensor garis infrared dan photodioda) maka dapat ditarik kesimpulan sebagai berikut: Perangkat keras yang digunakan dalam pembuatan alat ini antara lain mikrokontroler Arduino R3, sensor ultrasonik, sensor garis (infrared dan photodioda), motor servo, rangkaian penggerak robot dan komponen yang lainnya. Software yang digunakan dalam proses perakitan alat ini adalah dengan menggunakan bahasa pemrograman Bahasa Arduino dengan menentukan terlebih dahulu susunan pembuatan alat menggunakan flowchart. Dari hasil pengujian didapatkan kesimpulan bahwa masing-masing komponen telah bekerja dengan baik dan alat dapat bekerja dengan maksimal. 


\section{DAFTAR PUSTAKA}

[1] Al-Bahra bin Ladjamudin. 2005. Analisis dan Desain Sistem Informasi. Yogyakarta : Graha Ilmu.

[2] Budiharto, Widodo. 2006. Panduan Bagi Programmer .NET : Menguasai VB. NET Tingkat Lanjut. Jakarta. Elex Media Komputindo.

[3] Budiman. 2012. Pengujian Perangkat Lunak Menggunakan Black Box Pada Proses Pra Registrasi User Via Website, Makalah, halaman:4

[4] Fitriana, YuliaNur, 2012. Sistem Kontrol Lengan Robot Menggunakan Sinyal EMG Berbasis Mikrokontroller H8/3069F. Jakarta. Universitas Indonesia.

[5] Jatmiko, Pryio. 2015. Pengenalan Komponen Industri : part, plc dan touchscreen. Volume 1 dari electric 1 Kartanagari : PriyoJatmiko

[6] Ladjamudin. 2005. Analisis dan desain sistem Informasi. Yogyakarta: Graha Ilmu.

[7] Munawaroh, Isnatun. 2009. Komputer Dan Pembelajaran. Yogyakarta

[8] Nazir, Moh. 2005. Metode Penelitian. Jakarta :Ghalla Indonesia

[9] Nur Fitriana, Y. 2012. Sistem Kontrol Lengan Robot Menggunakan Sinyal EMG Berbasis Mikroontroler H8/3069F. Universitas Indonesia

[10] Siddiq, Asep Jafar 2012. Rekayasa Perangkat Lunak. Yogyakarta: CV ANDI OFFSET.

[11] Solichin, Annur. 2009. Rancang Bangun Lengan Robot (Arm Robot) Dengan Pengendalian Manual. Institut Pertanian. Bogor

[12] Sugiyono. 2013. Metode Penelitian Pendidikan, Kuantitatif dan Kualitatif. Bandung : CV Alfabetha.

[13] Sulaiman, A. 2012. Mikrokontroller bagi Pemula hingga Mahir. ARDUINO. http://buletin.balaielektronika.com diakses tanggal : 25 Mei 2017

[14] Syafudin, Raden Muhamad. 2012.Perancangan Sistem Kendali Gerak Lengan Robot Pengikut Gerak Lengan Manusia Berbasis Mikrokontroller. STMIK MDP. Palembang

[15] Syahwil, Muhammad. 2013. Panduan Mudah Simulasi dan Praktik Mikrokontroler. Arduino. Yogyakarta : Andi

[16] Syaripudin, Unyuk. 2010.Elektonika 2. Jakarta :Yudhistira

[17] Petruzella. 2001. ElektroniKa Industri, Yogyakarta: Andi.

[18] Putra. 2004. Belajar Mikrokontroler AT89C51/52/55: Teori dan Aplikasi, Edisi 2. Yogyakarta :Gava Media. 